\title{
Disturbance of Calcium Metabolism by Anticonvulsant Drugs
}

\author{
A. RICHENS, ${ }^{*}$ PH.D., M.R.C.P. ; D. J. F. ROWE, $†$ B.SC.
}

British Medical fournal, 1970, 4, 73-76

\begin{abstract}
Cummary: A survey of calcium metabolism in epileptic patients in a residential centre showed a subnormal serum calcium level in $22.5 \%$ of patients and a raised alkaline phosphatase in $29 \%$. Hypocalcaemia was related to high dosage of anticonvulsant drugs, to multiple drug therapy, and to the use of individual anticonvulsant drugs in the following order, with decreasing order of importance: pheneturide, primidone, phenytoin, phenobarbitone. Subnormal serum calcium levels occurred more commonly in patients with a raised liver alkaline phosphatase iseenzyme than in those whose phosphatase was mainly of bone origin.

Preliminary results of treatment with calciferol suggested that the disturbance of calcium metabolism was the result of vitamin $D$ deficiency. It is possible that anticonvulsant drugs accelerate the breakdown of vitamin $D$ by liver enzyme induction.
\end{abstract}

\section{Introduction}

During a clinical trial of Trinuride (pheneturide, phenytoin, and phenobarbitone) at the Chalfont Centre for Epilepsy, Chalfont St. Peter, Buckinghamshire, Wright (1965) reported that the serum alkaline phosphatase concentration rose in $20 \%$ of the patients treated. Nevertheless, $16 \%$ of control patients receiving phenytoin and phenobarbitone, but not pheneturide, showed a similar increase. Wright assumed that the enzyme was derived from the liver, though other tests of liver function were normal. Vas and Parsonage (1967) found no abnormality of liver, kidney, or bone function in patients with a raised alkaline phosphatase who were receiving pheneturide. More recently, however, Kruse (1968) reported that $15 \%$ of young epileptics showed $x$-ray evidence of osteomalacia, accompanied by a reduced serum calcium and phosphate, and a raised alkaline phosphatase. The severity of these changes depended on the number and dose of anticonvulsant drugs and on the duration of therapy.

Our present study was undertaken to determine whether calcium metabolism was disturbed in adults receiving anticonvulsants for major epilepsy, and whether the increased serum alkaline phosphatase was of liver or bone origin.

\section{Methods}

Fasting blood samples were taken from 160 residents with major epilepsy at the Chalfont Centre for Epilepsy; 75 were men and 85 women aged 16 to 70 (mean 36 ) years. All but three of these patients were receiving one or more of the major anticonvulsant drugs, phenytoin, phenobarbitone, primidone, and pheneturide. Many were receiving, in addition, various other anticonvulsant or tranquillizing drugs. Blood samples were taken also from a group of 82 controls ( 40 men and 42 women, mean age 34 years).

Serum calcium and phosphorus levels were determined with the routine analytical methods currently employed in the metabolic unit, University College Hospital. Serum calcium levels were corrected to a specific gravity of 1027 (Dent, 1962). Serum alkaline phosphatase and electrophoretic separation of its isoenzymes were estimated as described by

\footnotetext{
* Wellcome Research Fellow, Division of Clinical Pharmacology, Medical Professorial Unit, and Department of Clinical Neurophysiology, St.
Bartholomew's Hospital, London E.C.1. † Biochemist, Metabolic Unit, University College Hospital, London W.C.1.
}

Canapa-Anson and Rowe (1970), the proportions of liver, bone, and small-intestinal isoenzymes being estimated visually and expressed as a percentage by one of us (D.J.F.R.) who had no knowledge of the patients' treatment.

Statistical Methods.-Unless otherwise stated, standard Student $t$ tests were performed throughout with corrections for unequal variance where necessary. The serum alkaline phosphatase values showed a lognormal distribution, so a $t$ test was performed on logarithmic data. Results are expressed as the mean \pm one standard error.

\section{Results}

\section{Pilot Study}

Of 14 patients in the clinical trial of Wright (1965) 12 still had raised alkaline phosphatase levels, ranging from 13 to 29 King-Armstrong units (K.A.u.)/100 ml. Enzyme electrophoresis showed an increase of the liver fraction in eight patients, of the bone fraction in two, and of both fractions in the remaining two. Serum 5 -nucleotidase and alanine transaminase enzymes were normal in all patients. Serum calcium levels were below $9 \mathrm{mg} . / 100 \mathrm{ml}$. in five of these patients, despite normal serum albumin levels. These results suggested that calcium metabolism might often be impaired in adult epileptics, and hence a survey of one-third of the population of the Chalfont Centre was undertaken to confirm this observation and to determine whether this abnormality was related to anticonvulsant therapy.

\section{Serum Calcium}

The serum calcium levels of the patients were compared with those of 52 controls (Fig. 1). The mean levels were 9.25 \pm 0.03 and $9.73 \pm 0.05 \mathrm{mg} . / 100 \mathrm{ml}$., respectively, the difference between them being highly significant $(P<0.001)$. Thirty-six $(22.5 \%)$ of the patients had levels below $9 \mathrm{mg} . / 100 \mathrm{ml}$., whereas none of the controls had a level below this value. The mean serum albumin of the patients was $4.4 \mathrm{~g} . / 100 \mathrm{ml}$. (normal range $3.7-4.7 \mathrm{~g} . / 100 \mathrm{ml}$.), and those who had a subnormal serum calcium had a mean albumin of $4.3 \mathrm{~g} . / 100 \mathrm{ml}$.

To test for a relationship between anticonvulsant dose and serum calcium level, the dose of each of the four major anticonvulsant drugs was expressed as a score in units. The individual scores for each patient were added up to give a total representing the daily dose of major drugs. To equate the commonly prescribed doses of the four drugs, one unit was allowed for every $50 \mathrm{mg}$. of phenytoin or $30 \mathrm{mg}$. of

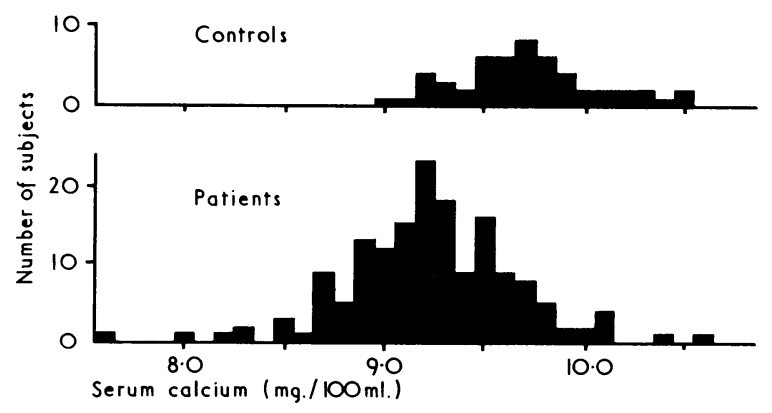

Fig. 1.-Histogram of the serum calcium levels (corrected for serum specific gravity) of the normal controls and patients. 


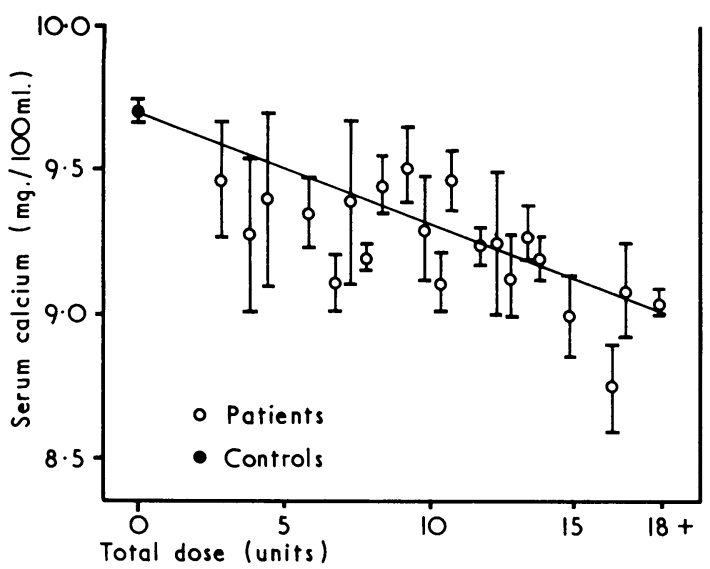

Fig. 2.-Relationship between serum calcium and the total daily dose of the four major anticonvulsants. Each open circle represents the mean ( $t$ S.E.) of the serum calcium of patients at each dose level. The closed circle represents the mean serum calcium of 52 normal controls.

phenobarbitone, and 1.5 units for every $250 \mathrm{mg}$. of primidone or $200 \mathrm{mg}$. of pheneturide. On this scale the mean dose level for the population under study was 10.5 units. A Spearman rank correlation test on the 160 observations showed a significant inverse correlation (Fig. 2) between the total daily dose of the four drugs and the serum calcium level $\left(r_{s}=0.17\right.$, $P<0.05$ ). Low serum calcium levels were found more frequently in patients receiving multiple drug therapy (Table I), but combined therapy inevitably produced a higher total drug dose.

Despite a similarity in the mean total dose levels of patients on phenobarbitone, phenytoin, or primidone the mean serum calcium was lower in patients receiving phenytoin than in those on phenobarbitone, and was still lower in those on

TABle I.-Relationship Between Serum Calcium and the Number of Major Anticonvulsant Drugs (Phenytoin, Phenobarbitone, Primidone, or Pheneturide) Prescribed

\begin{tabular}{|c|c|c|c|c|c|}
\hline $\begin{array}{l}\text { No. of } \\
\text { Drugs }\end{array}$ & $\begin{array}{l}\text { No. of } \\
\text { Cases }\end{array}$ & $\begin{array}{l}\% \text { with a } \\
\text { Low Serum } \\
\text { Calcium }\end{array}$ & $\begin{array}{c}\text { Mean Serum } \\
\text { Calcium } \\
\text { (mg./100 ml.) }\end{array}$ & $\begin{array}{c}\text { Mean Daily } \\
\text { Total Dose } \\
\text { (Units) }\end{array}$ & $P^{*}$ \\
\hline $\begin{array}{ll}\text { One } & . \\
\text { Two } & . \\
\text { Three } & .\end{array}$ & $\begin{array}{r}15 \\
102 \\
36\end{array}$ & $\begin{array}{r}7 \\
18 \\
47\end{array}$ & $\begin{array}{l}9 \cdot 48 \pm 0.12 \\
9 \cdot 29 \pm 0.04 \\
9.02 \pm 0.07\end{array}$ & $\left.\begin{array}{r}4 \cdot 8 \\
10.3 \\
13 \cdot 7\end{array}\right\}$ & $\begin{array}{l}<0.05 \\
<0.0025\end{array}$ \\
\hline
\end{tabular}

- Significance of difference between mean serum calcium levels.

TABLE II.-Relationship Between Serum Calcium and the Individual Major Anticonvulsant Drugs

\begin{tabular}{|c|c|c|c|c|c|c|}
\hline Drug* & $\begin{array}{l}\text { No.of } \\
\text { Cases }\end{array}$ & $\begin{array}{c}\% \text { with a } \\
\text { Low } \\
\text { Serum } \\
\text { Calcium }\end{array}$ & $\begin{array}{c}\text { Mean Serum } \\
\text { Calcium } \\
(\mathrm{mg} . / 100 \mathrm{ml} .)\end{array} \mid$ & $\begin{array}{c}\text { Mean } \\
\text { Daily } \\
\text { Total } \\
\text { Dose } \\
\text { (Units) }\end{array}$ & $\begin{array}{l}\text { Mean Daily } \\
\text { Dose of } \\
\text { Individual } \\
\text { Drug (mg.) }\end{array}$ & $\mathrm{Pt}$ \\
\hline $\begin{array}{l}\text { Phenobarbitone } \\
\text { Phenytoin . } \\
\text { Primidone } \\
\text { Pheneturide }\end{array}$ & $\begin{array}{r}102 \\
140 \\
77 \\
20\end{array}$ & $\begin{array}{l}22 \\
25 \\
30 \\
40\end{array}$ & $\begin{array}{l}9 \cdot 27 \pm 0.04 \\
9 \cdot 21 \pm 0.03 \\
9 \cdot 16 \pm 0.05 \\
9.01 \pm 0.09\end{array}$ & $\begin{array}{l}11.0 \\
11.2 \\
11.4 \\
13.9\end{array}$ & $\begin{array}{l}150 \\
260 \\
800 \\
500\end{array}$ & $\begin{array}{l}\text { N.S. } \\
<0.025 \\
<0.025 \\
<0.025\end{array}$ \\
\hline
\end{tabular}

* All patients receiving a particular drug have been included, regardless of any other drug therapy.

tSignificance of difference between mean serum calcium of patients receiving a particular drug and that of patients not receiving it.
TABLE IV.-Comparison of Drug Therapy in Hypocalcaemic and Normocalcaemic Patients

\begin{tabular}{|c|c|c|c|c|}
\hline & $\begin{array}{l}\text { Hypocalcaemic } \\
\text { (36) }\end{array}$ & $\underset{(124)}{\text { Normocalcaemic }}$ & $x^{2}$ & $\mathbf{P}$ \\
\hline Mean daily total dose: & 11.5 units & $10 \cdot 2$ units & & \\
\hline $\begin{array}{l}\text { Percentage on: } \\
\text { Phenobarbitone } \\
\text { Phenytoin .. } \\
\text { Primidone .. } \\
\text { Pheneturide .. } \\
\text { Triple therapy }\end{array}$ & $\begin{array}{l}61 \\
97 \\
64 \\
22 \\
47\end{array}$ & $\begin{array}{l}60 \\
85 \\
43 \\
10 \\
15\end{array}$ & $\begin{array}{c}3 \cdot 0 \\
3 \cdot 87 \\
3 \cdot 0 \\
14 \cdot 4\end{array}$ & $\begin{array}{l}\text { N.S. } \\
<0.05 \\
\text { N.S. } \\
<0.001\end{array}$ \\
\hline
\end{tabular}

TABLE V.-Alkaline Phosphatase Electrophoresis of Patients and Control

\begin{tabular}{|c|c|c|c|c|}
\hline \\
\hline Isoenzyme & $\begin{array}{l}72 \text { Controls } \\
160 \text { Patients }\end{array}$ & $\begin{array}{c}\text { Mean } \\
\text { (K.A.U./100 ml.) }\end{array}$ & $\begin{array}{c}\text { Range } \\
\text { (K.A.U./100 ml.) }\end{array}$ & $\begin{array}{c}\text { Range } \\
\text { ( } \% \text { of Total) }\end{array}$ \\
\hline 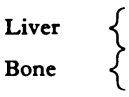 & $\begin{array}{l}\text { Controls } \\
\text { Patients } \\
\text { Controls } \\
\text { Patients }\end{array}$ & $\begin{array}{l}3 \cdot 3 \\
6 \cdot 2 \\
2 \cdot 4 \\
3 \cdot 7\end{array}$ & $\begin{array}{c}0.5-11.5 \\
0-23 \\
0.5-5.8 \\
0-23\end{array}$ & $\begin{array}{c}15-90 \\
0-100 \\
10-85 \\
0-100\end{array}$ \\
\hline
\end{tabular}

primidone (Table II). Though patients receiving pheneturide had the lowest mean serum calcium, 18 of the 20 were an three or more drugs and the mean total dose was higher.

Patients receiving double or triple therapy were subdivided into groups according to certain drug combinations (Table III). Those receiving two drugs were divided into two groups, whose treatment differed only by one receiving an average of $160 \mathrm{mg}$. of phenobarbitone daily and the other $830 \mathrm{mg}$. of primidone. The latter group had a mean serum calcium lower than the former, though the difference was not significant $(P<0 \cdot 1)$. With triple therapy serum calcium levels were lower in patients on primidone than in those on phenobarbitone, and lower with pheneturide than with primidone. Neither of these differences, however, was significant. Too few patients were on one drug alone to compare the effects of one drug with another. Similarly, too few were receiving any of the other anticonvulsant drugs for major epilepsy to allow meaningful analysis. Fourteen patients were receiving ethosuximide, and these had a mean serum calcium of $9.50 \pm$ $0.13 \mathrm{mg} . / 100 \mathrm{ml}$., which was significantly higher than that of the rest of the population $(P<0.05)$. This group, however, was receiving a slightly smaller total daily dose of the four major drugs ( 9.7 compared with 10.6 units).

Several features distinguished the drug therapy of the 36 patients who had low serum calcium levels (Table IV).

\section{Serum Alkaline Phosphatase}

The mean serum alkaline phosphatase level in the patients was 9.9 K.A.u. $/ 100 \mathrm{ml}$. while that of the controls was 5.9 K.A.u./100 ml. (Fig. 3), a highly significant difference ( $t$ test on $\log$ data, $P<0.001$ ). With the strict criteria of 10 and 12 K.A.u. $/ 100 \mathrm{ml}$. as the upper limit of the normal range in women and men, respectively, 47 patients $(29 \%)$ had a raised alkaline phosphatase. The incidence of hypocalcaemia was high in this group, $36 \%$ having levels below $9 \mathrm{mg} . / 100 \mathrm{ml}$. compared with $17 \%$ of those with a normal serum phosphatase $\left(\chi^{2}=6.0, P<0.02\right)$. Though more were receiving triple

\begin{tabular}{|c|c|c|c|c|c|c|c|c|c|}
\hline \multirow{2}{*}{\multicolumn{2}{|c|}{ Drug Combination }} & \multirow{2}{*}{ No. of Cases } & \multirow{2}{*}{$\begin{array}{l}\% \text { with a } \\
\text { Low Serum } \\
\text { Calcium }\end{array}$} & \multirow{2}{*}{$\underset{\substack{\text { Serum } \\
\text { Calcium }}}{\text { (mg. } / 100 \mathrm{ml} .)}$} & \multirow{2}{*}{$\begin{array}{l}\text { Mean Daily } \\
\text { Total Dose } \\
\text { (Units) }\end{array}$} & \multicolumn{4}{|c|}{ Mean Daily Dose of Each Drug (mg.) } \\
\hline & & & & & & Phenytoin & Phenobarbitone & Primidone & Pheneturide \\
\hline $\begin{array}{l}\text { Two Drugs*: } \\
\text { Phenytoin + phenobarbitone } \\
\text { Phenytoin + primidone } \quad .\end{array}$ & $\begin{array}{l}\cdots \\
\cdots\end{array}$ & $\begin{array}{l}64 \\
33 \\
\end{array}$ & $\begin{array}{l}18 \\
21\end{array}$ & $\begin{array}{l}9.33 \pm 0.05 \\
9 \cdot 20 \pm 0.07\end{array}$ & $\begin{array}{l}10 \cdot 5 \\
10 \cdot 3 \\
\end{array}$ & $\begin{array}{l}250 \\
260\end{array}$ & 160 & $\overrightarrow{830}$ & - \\
\hline $\begin{array}{l}\text { Three Drugs: } \\
\text { Phenytoin }+ \text { phenobarbitone }+ \\
\text { primidone } \\
\text { Phenytoin + phenobarbitone }+ \\
\text { pheneturide } \\
\begin{array}{c}\text { Phenytoin + primidone }+ \\
\text { pheneturide . . }\end{array}\end{array}$ & $\begin{array}{l}\cdots \\
\cdots\end{array}$ & $\begin{array}{r}20 \\
5 \\
11\end{array}$ & $\begin{array}{l}45 \\
40 \\
55\end{array}$ & $\begin{array}{l}9.10 \pm 0.10 \\
8.98 \pm 0.07 \\
8.92 \pm 0.14\end{array}$ & $\begin{array}{l}13 \cdot 7 \\
14 \cdot 6 \\
13 \cdot 3\end{array}$ & $\begin{array}{l}280 \\
280 \\
280\end{array}$ & $\begin{array}{l}120 \\
145 \\
-\end{array}$ & $\begin{array}{l}700 \\
- \\
750\end{array}$ & $\begin{array}{l}- \\
560 \\
420\end{array}$ \\
\hline
\end{tabular}

*The pharmacological properties of phenobarbitone and primidone make them usually unsuitable for combined therapy; only three patients received this combination. 


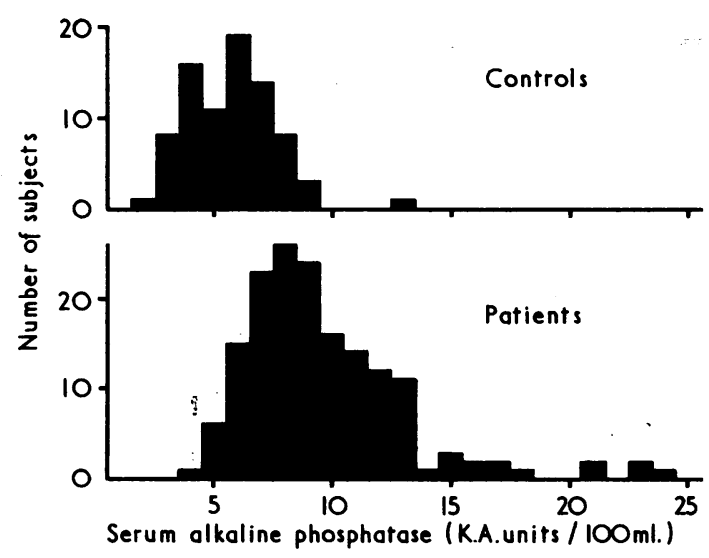

FIG. 3.-Histogram of the serum alkaline phosphatase levels of the normal controls and patients.

therapy ( $36 \%$ compared with $17 \%, \chi^{2}=6.0, \mathrm{P}<0.02$ ), and the total daily dose was marginally higher (10.8 compared with 10.4 units), no significant relationship emerged between the individual drugs and raised serum phosphatase levels.

An increase of both liver and bone isoenzymes accounted for the higher total serum levels found in the patients (Table V). The range of both fractions as a percentage was extreme, one patient having $100 \%$ liver isoenzyme with a total of 23 K.A.u. $/ 100 \mathrm{ml}$., while another had $100 \%$ bone isoenzyme with a similar total. This latter patient subsequently proved to have a low serum calcium and bone-biopsy evidence of osteomalacia (Dent, Richens, Rowe, and Stamp, 1970). Of the 47 patients with an increased alkaline phosphatase 28 showed increased activity confined to the liver fraction and 18 showed a rise of bone isoenzyme. The low serum calcium levels, surprisingly, occurred more often in the former group (12 out of 28 patients) than in the latter (4 out of 18). One remaining subject had a rise of both fractions, with a serum calcium of $7.6 \mathrm{mg} . / 100 \mathrm{ml}$.

Several younger patients (aged 16-25) had an unusually high proportion of bone isoenzyme, giving an absolute figure above 5 K.A.u. $/ 100 \mathrm{ml}$. In our experience the electrophoretic pattern of normal people has settled to the adult type by the late teens, whereas increased bone activity is usual at earlier ages. In this study only 1 out of 72 controls had a bone isoenzyme level greater than 5 K.A.u. $/ 100 \mathrm{ml}$, whereas 37 of the 160 patients had levels exceeding this figure.

\section{Serum Phosphorus}

The mean serum phosphorus of the patients $(3.60 \mathrm{mg} . / 100 \mathrm{ml}$.) was not significantly different from that of the normal controls $(3.64 \mathrm{mg} . / 100 \mathrm{ml}$.). No relationship could be found between serum phosphorus and serum calcium, patients with a low calcium having a mean serum phosphorus of $3.65 \mathrm{mg} . / 100 \mathrm{ml}$. Furthermore, there was no relationship between drug therapy or raised levels of alkaline phosphatase and the serum phosphorus.

\section{Discussion}

Analysis of the data produced by this survey was complicated by the multiplicity of combinations and dose levels of anticonvulsant drugs used in patients whose epilepsy had proved difficult to control. If the system devised for scoring the four major drugs to produce a total daily dose is accepted as valid, the hypocalcaemic effect of these drugs is obvious, and is dose-related. This system could not, of course, reveal any effects which were related to only one of the four drugs. Attempts at constructing dose/response curves with each drug separately were only partly successful, for other variables (such as the number of drugs and dose of the other three drugs) were not randomly distributed with respect to the dose of the drug being studied.

The finding (Table I) that serum calcium levels were inversely proportional to the number of drugs prescribed suggested either that combining drugs had a deleterious effect on calcium metabolism or that the total dose was the important factor in producing this abnormality. Unfortunately, these two variables were inseparable. Pheneturide was often used as a supplement in patients poorly controlled and already receiving a high dose of two drugs, so that the observation that this drug was the most likely to affect calcium metabolism could be explained either by the high intake of all drugs in patients receiving pheneturide or by the high incidence of triple or quadruple therapy in this group. This difficulty was to some extent resolved by comparing the serum calcium levels of those patients on phenytoin, phenobarbitone, and pheneturide with those on phenytoin, phenobarbitone, and primidone (Table III). The former had a lower mean calcium than the latter, but the numbers were too few for this difference to be significant. A similar analysis in patients receiving either two or three drugs in combination suggested that primidone was more likely to produce hypocalcaemia than was phenobarbitone, but the difference did not reach statistical significance. Hence the only conclusion possible was that some drugs affected calcium metabolism more than others, and that the most likely order, with decreasing order of importance, was pheneturide, primidone, phenytoin, and phenobarbitone. No account has been taken of the other drugs used in major epilepsy because of their infrequent use in the population studied. Those patients receiving the petit mal drug, ethosuximide, had a mean calcium significantly higher than that of the rest of the patients, suggesting that this drug might be free from any effect on calcium metabolism.

Our conclusions agree with those of Kruse (1968), who suggested that osteomalacia in children with epilepsy was related to the number and dose of anticonvulsants received, as well as to the duration of therapy. No evidence can be offered on this point, as all our patients had been receiving anticonvulsants for at least five years, but presumably the treatment has to be of a certain minimum duration to produce clinical evidence of osteomalacia. Probably growing children would be more sensitive to a disturbance of calcium metabolism than adults. This might explain the frequent rise of bone alkaline phosphatase seen in many of our younger patients, though few had abnormal serum calcium levels. Though Kruse (1968) found hypocalcaemia in his osteomalacic children, a report from India (Rudra, De, and Rudra, 1969) suggested that hypercalcaemia can occur, which these workers ascribed to hyperparathyroidism.

A study of our patients' diet showed that it was adequate in all respects. In addition, many of the patients under study were employed in farm or market-garden work, resulting in a greater than average exposure to sunlight. In any case, a dietary cause would not explain the relationship we found between drug therapy and serum calcium. Kruse (1968) found that his patients responded rapidly to relatively small doses of vitamin $D_{3}$, though the doses were not stated. Our patients are being investigated more fully before treatment is considered, but four patients who were unsuitable for further investigation, and who had serum alkaline phosphatase levels from 20 to 29 K.A.u. $/ 100 \mathrm{ml}$., were given 1,500 units of calciferol daily. After this treatment the serum alkaline phosphatase level slowly decreased and the proportion of bone isoenzyme became smaller, but serum calcium levels were little affected; nevertheless, when the dose was increased to 100,000 units daily serum calcium levels rapidly rose to normal, while the serum level of bone phosphatase rap:dly fell. The results of treatment will be presented more fully in a later report.

We conclude that the abnormalities found in our patients 
were the result of a deficiency of vitamin $D$. A possible mechanism for this is suggested by the significant association of hypocalcaemia and a raised liver phosphatase isoenzyme in the serum. Phenobarbitone and phenytoin can induce the liver enzymes responsible for the metabolism of many steroid compounds-for example, cortisol (Kuntzman, 1969)-and therefore probably vitamin $\mathbf{D}$ metabolism might be similarly affected. The importance of the liver in vitamin $D_{3}$ metabolism was underlined by the demonstration in patients with cirrhosis of a prolonged plasma half-life of the vitamin and a reduced renal excretion of its glucuronide conjugates (Avioli, Lee, McDonald, Lund, and DeLuca, 1967). Induction of liver enzymes by anticonvulsant drugs would shorten the biological half-life and lead to a tissue deficiency of the vitamin despite an adequate dietary intake. Subsequent osteomalacia would lead to an increase of bone alkaline phosphatase in the serum. This hypothesis is discussed further by Dent et al., (1970), and is at present being tested in rats by one of us (D.J.F.R.). The results of an initial study showed that liver enzyme induction with phenobarbitone significantly protected rats against loss of weight, hypercalcaemia, and renal calcinosis produced by acute administration of a high dose of calciferol. Further experiments are being performed to confirm these observations and to examine the other anticonvulsant drugs for a similar protective effect.

We would like to thank Dr. John Laidlaw, senior physician at the Chalfont Centre for Epilepsy, for allowing us to investigate patients under his care; the staff at Chalfont and University College Hospital who acted as controls; Professor C. E. Dent and Dr. T. C. B. Stamp for advice and discussion; the chemical pathology department at U.C.H. for serum protein estimations; and Mr. D. S. L. Lloyd for compuxing advice and programmes.

\section{REFERENCES}

Avioli, L. V., Lee, S. W., McDonald, J. E., Lund, J., and DeLuca, H. F. (1967). Fournal of Clinical Investigation, 46, 983.

Canapa-Anson, R., and Rowe, D. J. F. (1970). Fournal of Clinical Pathology. In press.

Dent, C. E. (1962). British Medical fournal, 2, 1419.

Dent, C. E., Richens, A., Rowe, D. J. F., and Stamp, T. C. B. (1970). British Medical Fournal, 4, 69.

Kruse, R. (1968). Monatsschrift für Kinderheilkunde, 116, 378.

Kuntzman, R. (1969). In Annual Review of Pharmacology, 9, 21

Rudra, M. N., De, S., and Rudra, M. S. (1969). New England Yourmal of Medicine, 280, 1242.

Vas, C. J., and Parsonage, M. J. (1967). Acta Neurologica Scandinavica, 43, Wright, J. A. (1965). Epilepsia, 6, 67.

\title{
Computer-held Clinical Record System-I, Description of System
}

\author{
L. J. OPIT, ${ }^{*}$ B.SC., F.R.C.S., F.R.A.C.S. ; F. J. WOODROFFE, $†$ M.B., B.S., M.R.C.P.
}

British Medical fournal, 1970, 4, 76-79

Summary: An account of a computer system for clinical record, storage, and retrieval is presented. Some details of its design and implementation are described.

\section{Introduction}

During the past five years there has been an increasing volume of literature devoted to the role of the computer in clinical medicine. Despite this, papers reporting on details of design and problems of working, or experimental, medical record computing systems are scarce. In this paper we attempt to describe in some detail how one computer system, King's College Hospital real-time computer project (Phase I), works.

\section{Present System}

The present King's College Hospital system provides a facility for up to four doctors working independently either to (1) enter registration details of patients or (2) record details of a history, physical examination, diagnosis, vital signs, and progress notes. The project also enables the senior ward nursing staff to record certain nursing routines prescribed for the patient.

Because at the outset it was proposed to install this system in two medical wards we restricted ourselves to providing mainly for the sort of information likely to be needed on a general medical ward. The device which the doctor uses to record his findings is a visual display unit (Fig. 1). This is a small television-like display screen with an attached keyboard, and is kept on a mobile trolley in the ward.

- Senior Lecturer, King's College Hospital Computer Unit, London S.E.5. t Consultant Physician to the Forest Group of Hospitals. Present appointt Consultant Physician to the Forest Group of Hospitals. Present appointment: Senior Research
sity of Birmingham.
The information which the doctor records by using the visual display unit is filed away on a magnetic storage device, which in the King's system is an exchangeable disc. At the same time as the messages are filed to the disc they are copied on to two magnetic tapes. These tapes are kept for only 24 hours and provide a means of reconstructing the whole of the last 24-hour period up to the time of any breakdown. Every message about a patient is stored on an openended file on this disc, the patient's record being identified by name and hospital number. These messages are kept logically, in the order in which they arrive. As well as the capacity to record information about each patient the visual display unit may be used to inspect messages already existing in the patient's file. These messages are displayed on the visual display unit screen, one at a time, and by typing the number

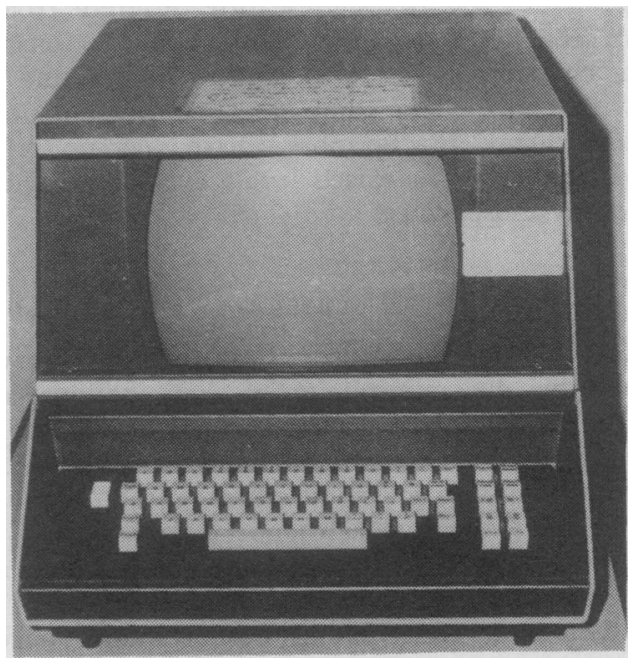

Fig. 1.-Visual display unit. 